IZA DP No. 5400

The IZA Evaluation Dataset:

Towards Evidence-Based Labor Policy-Making

Marco Caliendo

Armin Falk

Lutz C. Kaiser

Hilmar Schneider
Arne Uhlendorff

Gerard J. van den Berg

Klaus F. Zimmermann

December 2010 


\title{
The IZA Evaluation Dataset: Towards Evidence-Based Labor Policy-Making
}

\author{
Marco Caliendo \\ IZA, DIW Berlin and IAB Nuremberg
}

Armin Falk

University of Bonn and IZA

Lutz C. Kaiser

FHöV NRW, DIW Berlin and IZA

Hilmar Schneider

IZA and DIW Berlin

Arne Uhlendorff

University of Mannheim, DIW Berlin and IZA

Gerard J. van den Berg

University of Mannheim and IZA

Klaus F. Zimmermann

IZA, DIW Berlin and University of Bonn

\section{Discussion Paper No. 5400 \\ December 2010}

\author{
IZA \\ P.O. Box 7240 \\ 53072 Bonn \\ Germany \\ Phone: $+49-228-3894-0$ \\ Fax: +49-228-3894-180 \\ E-mail: iza@iza.org
}

\begin{abstract}
Any opinions expressed here are those of the author(s) and not those of IZA. Research published in this series may include views on policy, but the institute itself takes no institutional policy positions.

The Institute for the Study of Labor (IZA) in Bonn is a local and virtual international research center and a place of communication between science, politics and business. IZA is an independent nonprofit organization supported by Deutsche Post Foundation. The center is associated with the University of Bonn and offers a stimulating research environment through its international network, workshops and conferences, data service, project support, research visits and doctoral program. IZA engages in (i) original and internationally competitive research in all fields of labor economics, (ii) development of policy concepts, and (iii) dissemination of research results and concepts to the interested public.
\end{abstract}

IZA Discussion Papers often represent preliminary work and are circulated to encourage discussion. Citation of such a paper should account for its provisional character. A revised version may be available directly from the author. 


\section{ABSTRACT \\ The IZA Evaluation Dataset: Towards Evidence-Based Labor Policy-Making *}

The evaluation of labor market policies has become an important issue in many European countries. In recent years, a number of them have opened their administrative databases for evaluation studies. The advantages of administrative data are straightforward: they are accurate, contain a large number of observations (in some cases the whole population) and usually cover a long period of time. However, the information contained in administrative data is normally limited to administrative purposes. Therefore, information that might be relevant for economic modeling is often absent. The IZA Evaluation Dataset aims to overcome such limitations for Germany by complementing administrative data from the Federal Employment Agency with innovative survey data. The administrative part of the dataset consists of a large random sample of inflows into unemployment in Germany from 2001 to 2008 and contains around 920,000 individuals. The complementary survey covers a panel of more than 17,000 individuals who entered unemployment between June 2007 and May 2008. They were initially interviewed shortly after becoming unemployed and then again one year later. In addition, a quarter of individuals were interviewed already after six months. The survey data also contain information on search behavior, ethnic and social networks, psychological factors, (non-)cognitive abilities, and attitudes. This paper describes the sampling and contents of the IZA Evaluation Dataset and outlines the future development.

JEL Classification: J68, H43, C81

Keywords: evaluation, labor market policies, survey and administrative data, attitudes, behavior, skills

Corresponding author:

Klaus F. Zimmermann

IZA

P.O. Box 7240

D-53072 Bonn

Germany

E-mail: zimmermann@iza.org

\footnotetext{
* The creation of the IZA Evaluation Dataset is financed through core IZA research funds. We thank the German Science Foundation for financial support granted through SPP 1169 "Flexibility in Heterogeneous Labour Markets" which allowed for two complementary survey modules, one on cognitive skills and one on migration background. The IAB (Nuremberg) kindly gave us permission to use the administrative data as input. We thank the Editor, two anonymous referees and our colleagues Stefan Bender and Steffen Kaimer from the Institute for Employment Research in Nuremburg for helpful comments on an earlier draft.
} 


\section{Introduction}

In modern welfare states, active labor market policies (ALMP), such as training programs, public employment programs and wage subsidies, are intended to reintegrate the unemployed back into the labor market. However, the related instruments are not always effective or efficient. For policy decision-making, objective assessments of the impacts of such programs are necessary.

In order to obtain reliable estimates for the impact of ALMP and to understand why and how programs do or do not work, both appropriate econometric methods and suitable data are required. In recent years, many European countries have opened their administrative databases for scientific research. The advantages of administrative data are straightforward: they are relatively accurate, contain a large number of observations (in some cases the whole population) and usually cover a long period of time. Recent examples for evaluation studies based on administrative datasets have been conducted by Crépon, Ferracci and Fougère (2007) for France, Sianesi (2008) for Sweden, Heinrich, Mueser and Troske (2005) and Black et al. (2003) for the US, and Schneider and Uhlendorff (2006), Fitzenberger and Völter (2007), Lechner, Miquel and Wunsch (2007) and Caliendo, Hujer and Thomsen (2008) for Germany.

However, administrative data do not usually contain information on individual characteristics such as social networks, personality traits, cognitive skills, attitudes or ethnic identity. Examples for recent studies that show the relevance of such characteristics are Borghans et al. (2008), Anger and Heineck (2010), Bonin et al. (2007), Constant and Zimmermann (2008), Constant, Gataullina and Zimmermann (2009), Constant, Roberts and Zimmermann (2009), and Aydemir (2011). Moreover, 
administrative datasets usually contain no direct observation of variables describing job search behavior, such as reservation wages, search intensity or search channels. The same is true for information such as job satisfaction or individual expectations of leaving unemployment or participating in ALMP programs in the near future.

The IZA Evaluation Dataset aims to overcome such limitations by complementing administrative data of the German Federal Employment Agency with innovative survey data. The administrative part of the dataset consists of a large random sample of inflows into unemployment in Germany from 2001 to 2008 and contains around 920,000 individuals. The information is drawn from the Integrated Employment Biographies (IEB) provided by the Research Data Center (FDZ) of the Institute for Employment Research (IAB). The IEB are based on administrative social security records relevant for pension claims and unemployment insurance. In addition to employment spells and periods of program participation, the records of the IEB comprehensively mirror unemployment spells of employees in Germany (see Zimmermann, Kaimer and Oberschachtsiek, 2007, for details).

The complementary survey covers a panel of around 17,400 individuals who entered unemployment between June 2007 and May 2008. They were interviewed for the first time as close as possible to the point in time when they became unemployed and a second time one year later. Selected cohorts were additionally interviewed six months after the first wave. A final survey round is about to commence three years after the first wave.

The survey is conducted by a professional survey institute. The data collected also cover information on search behavior, ethnic and social networks, psychological factors, 
cognitive and non-cognitive abilities, and attitudes. Compared to current household surveys, such as the German Socio-Economic Panel Study (SOEP), the main advantages of the IZA Evaluation Dataset are the large sample size of unemployed individuals, the accuracy of employment histories, the innovative set of survey information and the fact that the survey measures important characteristics shortly after entry into unemployment. The survey data can also be merged retrospectively with administrative information from the IEB if respondents agree to this.

The IZA Evaluation Dataset offers many new perspectives for labor market research. This paper describes the sampling approach, the content of the administrative and the survey part of the IZA Evaluation Dataset, presents some descriptive statistics and outlines the future development.

\section{Population of Interest and Sampling Approach}

The target population of the IZA Evaluation Dataset consists of people entering unemployment in Germany. As a basis, the IEB was used for a random draw of the administrative sample of the IZA Evaluation Dataset. In our case, each individual with at least one entry into unemployment between January 2001 and December 2008 was considered for the drawing procedure.

In addition, sampling was based on the 'birthday concept', in which 17 separate days were randomly selected out of 365 days of a year, excluding February 29. The sampling scheme was designed so that there was an equal distance between the days, resulting in an equal distribution across the entire calendar year. Each person with a birthday on one of these sampling days and entry into unemployment between January 2001 and 
December 2008 is part of the sample. The birthday concept makes sure that the resulting sample yields a representative picture of the population of interest.

The number of sampling days approximately constitutes the relative sample size according to the formula 'number of sampling days $/ 365^{\prime 1}$. With 17 sampling days, this corresponds to a $4.66 \%$ sample of the total population of entrants into unemployment. It was estimated in advance that around $10 \%$ of the unemployed enter into an ALMP measure during their unemployment spell. With 7 to 8 million entries into unemployment per year, including multiple entries of the same individuals, it was expected that 17 birthdays would allow for more than 30,000 program participants per year.

For an analogous drawing of survey participants, we had to use a different process in order to time the initial interviews as close as possible to entry into unemployment. This is important for achieving a reference measurement for the assessment of the impact of ALMP.

Unfortunately, the IEB is not suited as a basis for close to event sampling, due to a significant time lag between real event and data availability in the IEB. The time consuming process of compiling administrative data means it may take up to six months until an unemployment record enters the IEB. Moreover, the IEB are updated only once a year. Accordingly, the time lag between real entry into unemployment and its visibility in the IEB may take up to 18 months. The time consuming compilation process for the IEB arises from the fact that the administrative process generating the data is not based

\footnotetext{
1 In fact, birthdays are not completely equally distributed over the year and between different years. During the 1960's until the mid 1970 's monthly birth figures showed a high in March and a low in November with a percentage difference from the annual mean of up to 14 percentage points. Since the mid 1970's, the highs have shifted towards July and also the related percentage differences have approximately reduced by half. Nevertheless, one could fairly expect that the sampling procedure is robust against critical selectivity bias.
} 
on person-related records containing all the relevant information. Instead it is based on several independent data collection processes (e.g. monthly unemployment registration, monthly computation of benefit claims, monthly participation in ALMP etc.). Historically, this used to be the most efficient way for producing recent aggregate figures. For generating individual records, the different files have to be merged over time and per individual, sometimes according to certain heuristics due to deficiencies regarding unique identifiers.

To overcome the disadvantage of the IEB for close to event sampling, a pre-product of the IEB, the monthly unemployment inflow statistics (AST) of the Federal Employment Agency had to be utilized (Bundesagentur für Arbeit, 2009). The data are generated when individuals register as unemployed at their local labor agency and cover a restricted selection of variables, such as date of registration, sex, age, profession and qualification. Based on the AST, the time lag between entry into unemployment and visibility in the data can be reduced to one month. However, one has to take into consideration that between visibility in the AST and the timing of the interview, additional time is required for sampling, sending out announcement letters to the potential respondents and other similar administrative procedures. By and large, the time lag between entry into unemployment and interviewing amounts to about two months. 


\section{Chart 1: Generation of the IZA Evaluation Dataset}

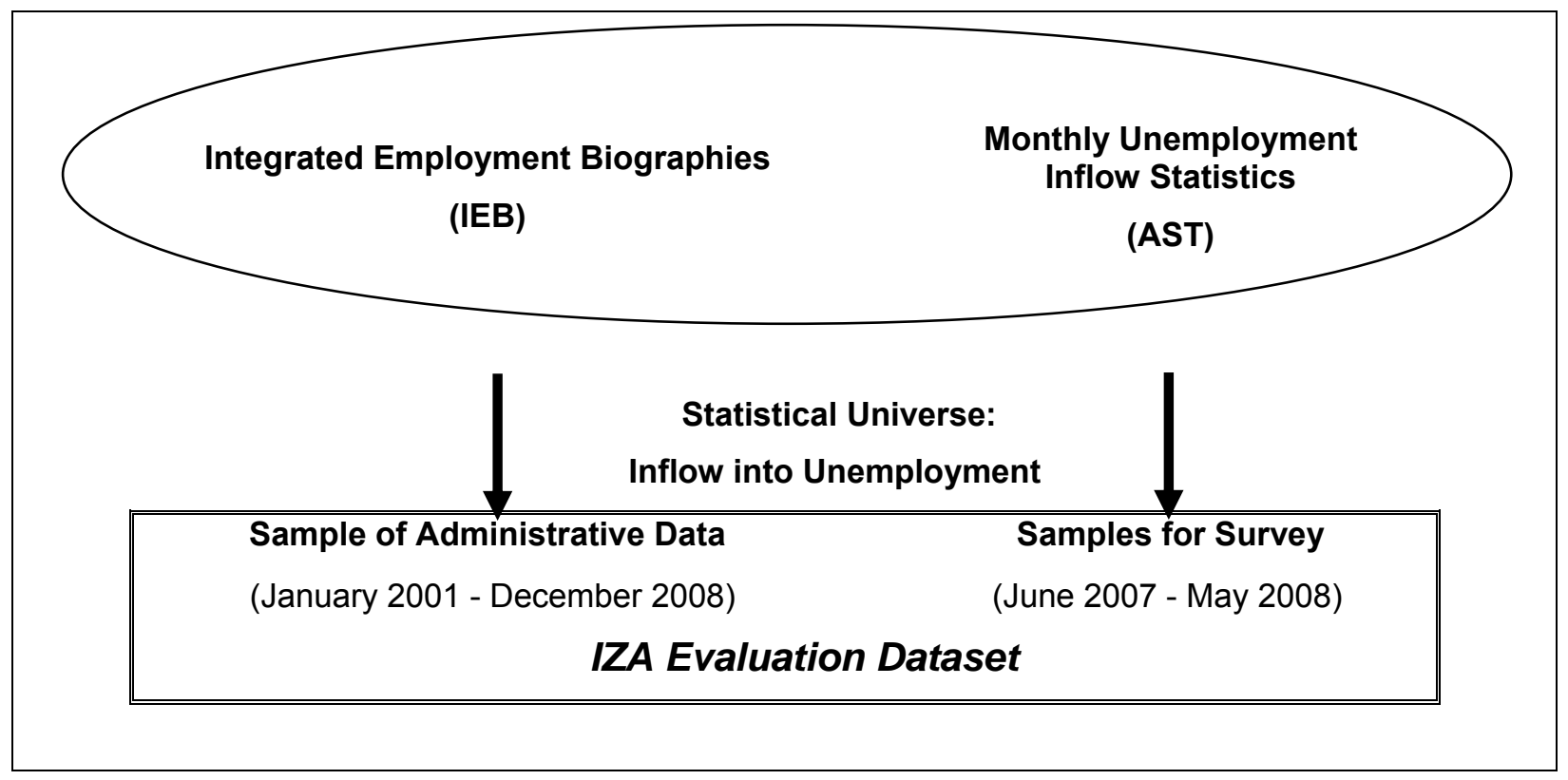

It needs to be mentioned that the concept of 'entry into unemployment' is somewhat 'fuzzier' in the AST compared to the IEB. For example, merely re-entering after an artificial interruption due to sickness or similar reasons is reported as an entry into unemployment in a significant number of cases in the AST. Such cases had to be filtered out in advance. Apart from that, however, AST and IEB are congruent with regard to the statistical universe of entries into unemployment, and AST records are successively incorporated into the periodic update process of the IEB.

For the survey dataset, 34 sampling days were used, which corresponds to a $9.32 \%$ gross sample. These 34 sampling days include the 17 sampling days of the IEB sample as a subset. The oversampling for the survey was necessary in order to compensate for various reasons of non-response. 
Based on this sample, 12 monthly AST entry cohorts were initially surveyed covering an observation period from June 2007 to May 2008. For those respondents who agreed to have their data merged with administrative data of the Federal Employment Agency, it is possible to combine the survey data retrospectively with the related administrative data.

\section{The Sample of Administrative Data}

In administrative terms, entry into unemployment is defined as registered unemployment at the Federal Employment Agency or a municipal welfare authority. To register as unemployed, a person must be employable and looking for a job. Registered jobseekers are allowed to work up to 15 hours per week without losing their status as unemployed. For each member of our administrative sample of entrants into unemployment, information on employment and benefit history is available up to the year 1993, based on information from the IEB.

The IEB data are organized as a compilation of five separate administrative data sources: employment histories $(\mathrm{BeH})$, unemployment benefit/unemployment assistancehistories (LeH), maintenance allowance histories (LHG/XLHG), program participation histories (MTH), and employment seeking histories (ASU/XASU) ${ }^{2}$. Unfortunately, not each of these histories covers the full time period since 1993. Only BeH and LeH data have been recorded since 1993, while MTH and ASU only started in 2000 and LHG/XLHG in 2005, when maintenance allowances were introduced. Moreover, time lags between event and entry into the data are specific to each data source and

2 See Jacobebbinghaus and Seth (2007) and Dundler (2006) for a general description of the IEB. Further details about the IEB structure can be found in Zimmermann, Kaimer and Oberschachtsiek (2007) and Kruppe et al. (2008). Maintenance allowance refers to welfare payments introduced in 2005. Dataset names extended by a preceding $X$ indicate original data from municipal welfare authorities. 
consequently, the end of recording also differs between these data sources. Chart 2 indicates the resulting observational window for each dataset.

The data are provided as spell data with daily accuracy. Parallel spells such as being registered as unemployed and working in a minor job are recorded separately ${ }^{3}$. The available information covers employment status, occupation, sector, daily wage, unemployment benefits and related replacement wages, benefit sanctions, contact frequency with the employment agency, and demographics, including sex, age, citizenship, education, marital status, number and age of children, health status and region. Information on program participation contains, program type and duration, premature termination and eventually program costs as well. Employment spells come with an identifier for plant affiliation, which allows for identification of job-to-job mobility.

However, due to their administrative nature, the data face some drawbacks. The IEB only contains information relevant to the social security registers. Periods in which people work as self-employed or as civil servants are not covered by the IEB because the self-employed and civil servants are not subject to social insurance. People who have never contributed to social insurance and never registered as job-seekers or participated in an ALMP program by the FEA are therefore not contained in the IEB. The similar applies to schooling spells, periods of compulsory military service and community service and periods of maternity leave. To some extent, such periods are covered implicitly, since each spell contains information on reasons why it began and ended. Moreover, information on educational status is not available for each individual contained in the registers. Information on hours worked is only available in a rough classification, if at all. A minor drawback from a practical perspective is that wages are

3 Jaenichen et al. (2005) describe the spell splitting of the IEB and some related problems in detail. 
censored at the social security contribution ceiling, which approximately amounts to the 2.1 fold of average earnings.

\section{Chart 2: Observational Periods for Subsets of the Integrated Employment Biographies (IEB 8.01 - June 2010)}

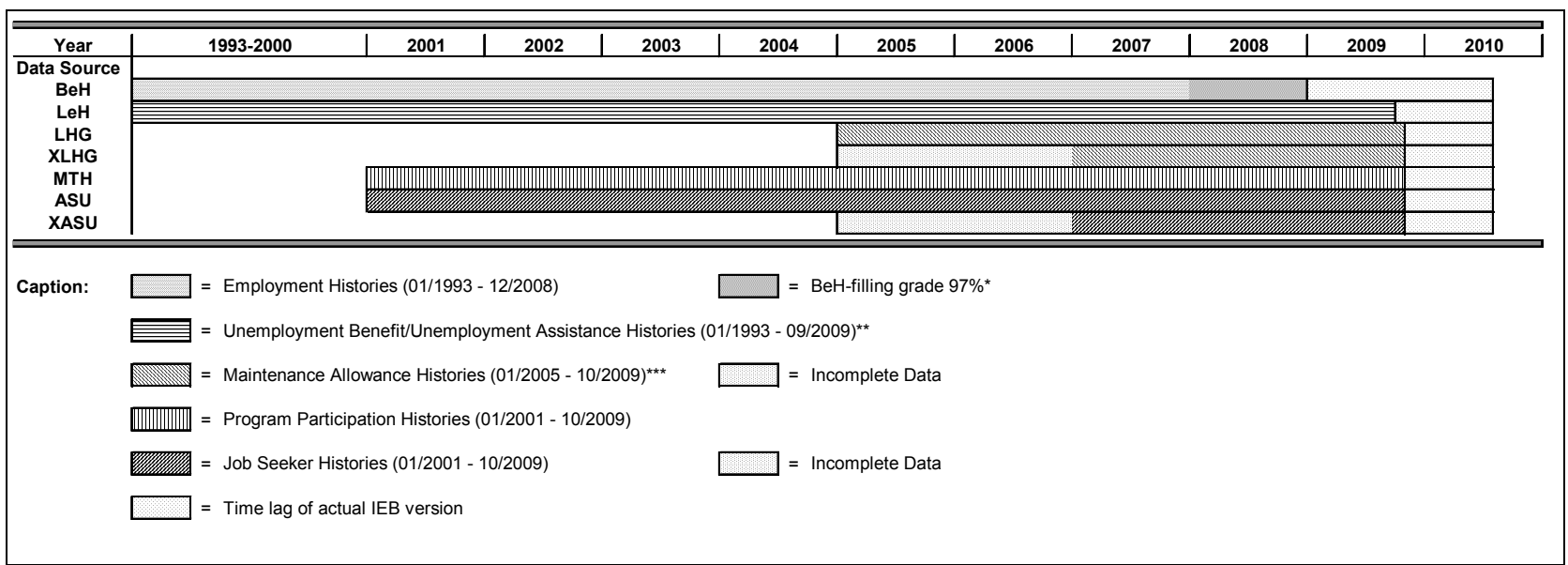

\footnotetext{
Notes: * The entity of employment spells is incomplete for 2008 due to a registration lag. Firms are allowed to register employees up to two years after the end of a calendar year. Currently, the filling grade of the IEB for 2008 is roughly $97 \%$. Therefore, employment spells ending at the end of 2007 may in fact have lasted to 2008 and beyond. Moreover, spells starting in 2008 may provisionally be missing or incomplete.

** Unemployment Assistance Histories ('Arbeitslosenhilfe, Alhi') occur only until 12/2004, since the 'Alhi' benefit system was abolished following the Hartz-Reform.

*** Maintenance Allowance Histories start in January 2005 as a new benefit system merging the former unemployment assistance ('Alhi') and social welfare ('Sozialhilfe').
}

Our administrative sample of the IZA Evaluation Dataset contains some 920,000 individuals with at least one entry into unemployment within the period from 2001 to 2008 , with around $2,300,000$ entries into unemployment. For $54 \%$ of the drawn individuals, the sample contains information on program participation, and for $74 \%$ of them, information on plant affiliation is available.

Chart 3 displays the number of unemployment entries per year, comparing the entire population of the IEB and the IEB-sample of the IZA Evaluation Dataset. It indicates a remarkable decline since 2005, which is in accordance with the rapid decline of unemployment in Germany since that year. 


\section{Chart 3: Comparison of Unemployment Entries per Year between the IEB and IEB Sample}

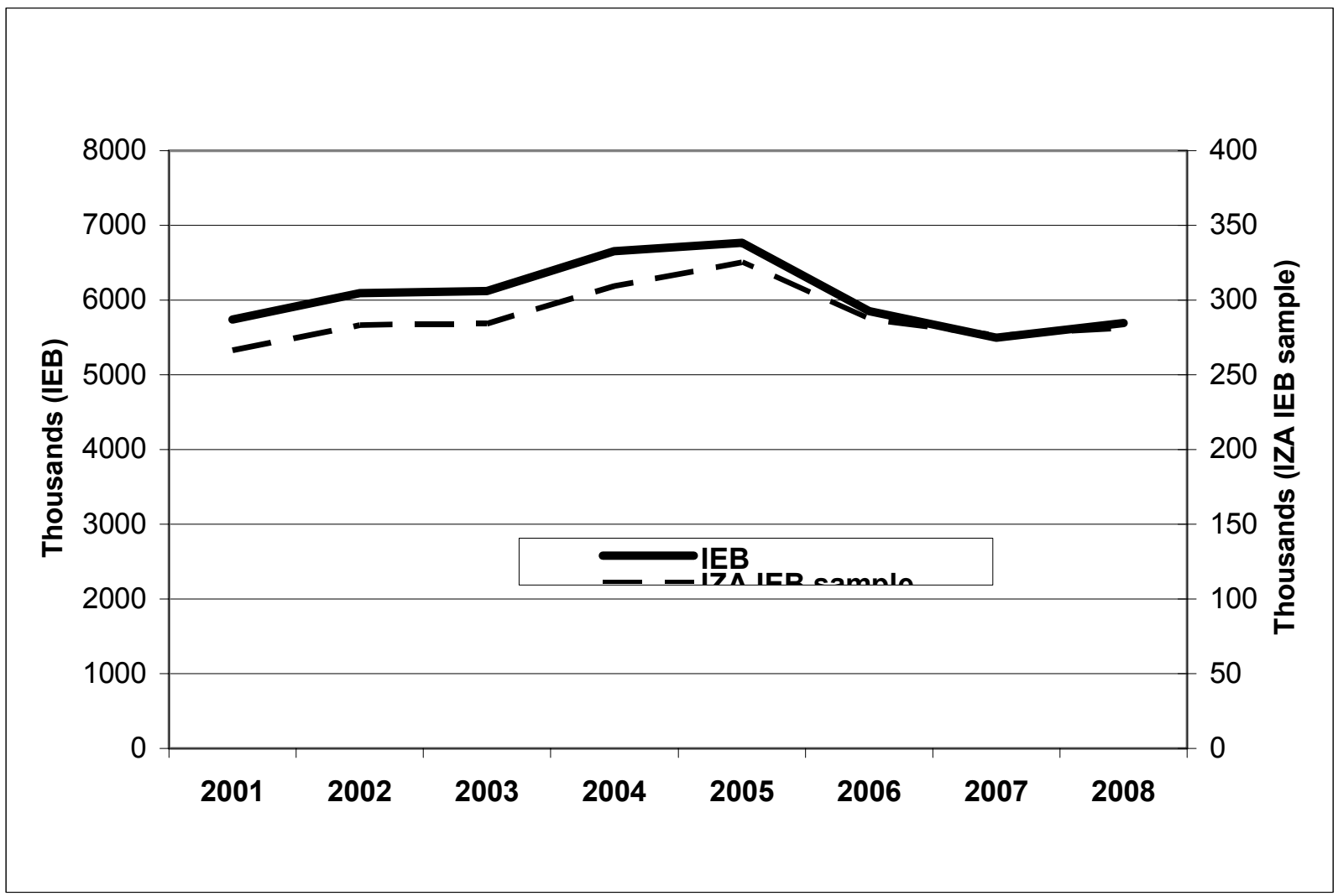

Note: Differences to official statistics are resulting from our filtering procedure intended to exclude (re-)entries into unemployment after sickness or ALMP program participation.

Source: IEB 8.01 - June 2010; IAB documentation; own computations.

Some main descriptive information for the IEB inflow statistics and the generated IEB sample of the IZA Evaluation Dataset are compared in Table 1. The figures show that only minor discrepancies occur between the IEB (inflow statistics) and the generated IEB sample. 


\section{Table 1: Comparison of Main Socio-Demographic Characteristics between the} IEB and IEB Sample

\begin{tabular}{lcc}
\hline \hline Database & IEB (inflow statistics) & IEB sample \\
\hline Male & 57.9 & 58.0 \\
Female & 42.1 & 42.0 \\
\hline Natives & 85.1 & 85.4 \\
Non-natives & 14.9 & 14.6 \\
\hline $16-24$ & 24.9 & 23.0 \\
$25-34$ & 25.1 & 25.8 \\
$35-44$ & 24.5 & 24.5 \\
$45-54$ & 18.4 & 18.8 \\
$55+$ & 7.2 & 7.9 \\
\hline \hline
\end{tabular}

Note: Differences to official statistics are resulting from our filtering procedure intended to exclude (re-)entries into unemployment after sickness or ALMP program participation.

Source: IEB 8.01 - June 2010; IAB documentation; own computations.

\section{$4 \quad$ The Survey Sample}

As previously mentioned the initial wave of the survey covers the period between midMay 2007 and mid-June 2008 and consists of 12 monthly cohorts. Each cohort starts in the middle of a month and ends in the middle of the following one. This corresponds to the time period used by the Federal Employment Agency for monthly reporting based on the AST. The end date of a statistical month determines its month label. For example, the statistical month of June in fact refers to the period mid-May to mid-June. Only after a statistical month is completed can the data be used for statistical analysis and for random draws of entries into unemployment. Table 2 displays the reference period for each statistical month contained in the survey sample of the IZA Evaluation Dataset. 
Table 2: Reference Periods of Statistical Months used in the Initial Wave of the Survey Sample

\begin{tabular}{cccc}
\hline \hline Cohort (\#) & Statistical month & Cohort & Statistical month \\
\hline $06 / 2007(1)$ & $05 / 15-06 / 142007$ & $12 / 2007(7)$ & $11 / 15-12 / 122007$ \\
$07 / 2007(2)$ & $06 / 15-07 / 162007$ & $01 / 2008(8)$ & $12 / 132007-01 / 122008$ \\
$08 / 2007(3)$ & $07 / 17-08 / 142007$ & $02 / 2008(9)$ & $01 / 13-02 / 142008$ \\
$09 / 2007(4)$ & $08 / 15-09 / 132007$ & $03 / 2008(10)$ & $02 / 15-03 / 132008$ \\
$10 / 2007(5)$ & $09 / 14-10 / 152007$ & $04 / 2008(11)$ & $03 / 14-04 / 142008$ \\
$11 / 2007(6)$ & $10 / 16-11 / 142007$ & $05 / 2008(12)$ & $04 / 15-05 / 142008$ \\
\hline \hline
\end{tabular}

The initial observation period of the survey sample is a time of a strong recovery of the German labor market. This period of recovery lasted until the end of 2008 , when the economic crisis hit the German labor market. Between January 2005 and December 2008, registered unemployment fell from 5 million to 3.1 million. This period was followed by a relatively short period of stagnation until the beginning of 2010 . Since then, the labor market has once again been recovering. However, as can be concluded from Chart 3 , the number of entries into unemployment has remained relatively stable since 2001. This indicates that the economic recovery has primarily affected average unemployment duration rather than inflow into unemployment.

According to AST statistics, entry into unemployment is technically defined as a registration of unemployment after a preceding period of not being registered as unemployed. From an administrative point of view, sickness or participation in an ALMP leads to a termination of registered unemployment. From an economic perspective, this may be viewed differently. Therefore, we imposed a filtering procedure on the sampling process in order to identify entries into unemployment fitting the economic perspective. In doing so, the following exclusion rules were applied:

(1) Individuals exclusively receiving maintenance assistance (German Social Code II legislation, SGB II) right from the beginning of their unemployment spell had to be 
omitted from sampling, as SGB II records were highly incomplete and inconsistent in the AST data during the initial sampling period. Hence, the sampling was restricted to the population registered at the Federal Labor Agency (German Social Code III legislation).

(2) Individuals above the age of 54 when entering unemployment were excluded in order to focus on the core population that is addressed by ALMP in Germany.

(3) Individuals who had already participated in surveys of the IAB or other research institutes were excluded in order to avoid undesirable effects of multiple survey participation. ${ }^{4}$

(4) Entrants into unemployment who had already been interviewed as part of a previous cohort were excluded from later cohorts.

(5) Entrants into unemployment who had already been selected for a previous cohort, but refused to participate in the survey when contacted, were also excluded from later cohorts.

(6) Individuals who re-registered as unemployed after a period of sickness or sanctions were excluded if the 'true' start of their unemployment spell referred to an earlier month.

(7) Finally, individuals registered as unemployed within the statistical reference month but who already possessed a new employment contract or who had participated in an ALMP program four weeks prior to their unemployment registration of the statistical reference month were excluded as well.

4 It is unlikely that the random nature of our sample is impaired by such a selection, since random selection based on the birthday approach is commonly used by the IAB for sampling from the IEB. 
Exclusion rules 1-3 were executed as integral part of the random drawing process from the AST records. According to the sampling process and the filtering rules described above, a specific AST sample was generated for each cohort at the Institute for Employment Research and delivered to IZA.

Based on these files, potential interviewees were randomly selected by the survey institute, considering exclusion rules 4 and 5 . Those selected received a letter prior to being contacted by the survey institute, informing them about the background of the survey and the fact that participation was voluntary. Exclusion rules 6 and 7 had then to be checked at initial contact with potential survey respondents.

The interviews were performed by means of computer assisted telephone interviews (CATI). For the two most important immigrant groups in Germany, Russians and Turks, the interviews were carried out in their native language in case German language skills were insufficient.

The fieldwork phase was restricted to four weeks in order to avoid too large time lags between the time of entering unemployment and the timing of an interview. In some cases, however, it could take longer if respondents who were contacted within the survey period were asked to be interviewed later. Table 3 describes average time lags in days between the presumed date of entry into unemployment and the actual date of the interview in wave 1 . Since the exact date of the commencement of unemployment within a statistical month is not recorded in the AST data, each time lag falls within two benchmarks: the time distance between the interview date and the first day of a statistical month ('worst case') and time distance between the interview date and the last day of a statistical month ('best case'). As an intermediate case, one could define the 
average of best and worst case for each respondent. In terms of intermediate cases, the average time lag between the beginning of unemployment and the date of the first interview amounts to a little over two months. Even in the worst case scenario, it is less than three months on average.

Table 3: Average Time Lag in Days between Commencement of Unemployment and the Date of Initial Interview

\begin{tabular}{lcccc}
\hline \hline & Mean & Median & Min & Max \\
\hline Best case & 55.0 & 52.0 & 35.0 & 117.0 \\
Intermediate case & 69.5 & 66.5 & 48.5 & 131.5 \\
Worst case & 84.0 & 81.0 & 62.0 & 146.0 \\
\hline \hline
\end{tabular}

Notes: Best case: unemployment entry at last day of statistical month.

Worst case: unemployment entry at first day of statistical month.

Intermediate case: average of worst and best case. Own computations based on wave 1 of the IZA Evaluation Dataset.

Follow-up interviews were carried out in several steps. For each monthly cohort, a second wave was conducted one year later, referring to the period June 2008 to May 2009. The first half of the second wave still fell into a period of economic recovery. However, the second half covered a period of stagnation, which lasted until early 2010. A third wave is currently being conducted, three years after the first wave. Chart 4 gives an overview concerning the entire survey schedule. 


\section{Chart 4: Survey Schedule - IZA Evaluation Dataset}

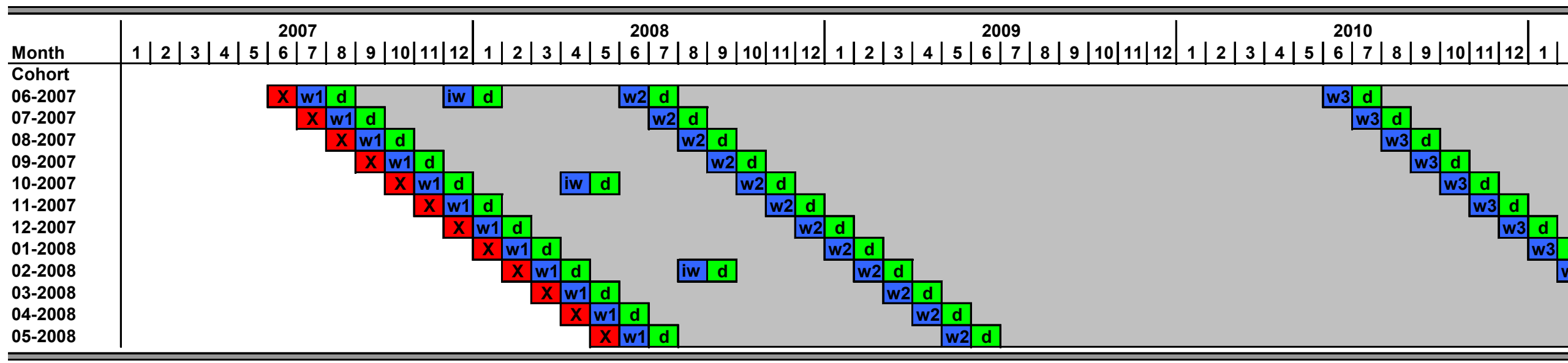

Caption:

$=$ entry into unemployment

w1 $=$ wave 1

w $=$ interim wave

2 $=$ wave 2

w3 = wave 3

d = data availability 
Each cohort of the initial wave was surveyed with a base module that contained the following sections:

(1) introduction, validation of filtering rules

(2) process of entering unemployment (status before entering unemployment, reason for becoming unemployed)

(3) migration (migration background, citizenship, year of immigration, religious affiliation, religious intensity, affiliation with home and host culture, language skills and usage)

(4) program participation (expectations, process of program assignment, content, satisfaction)

(5) educational attainment, vocational training (highest qualification, German or foreign degrees)

(6) educational history, training history, employment history, program participation, unemployment, other activities

(7) search activities, reservation wages (search channels, dependent and selfemployment, earned income, benefits, sanctions)

(8) personality traits, health status, life satisfaction, networks (individual habits, physical and mental health, contacts in the neighborhood, number of friends)

(9) household structure, household income (living with partner, number and age of children, sources of income, debts, housing)

In addition, three selected cohorts (June and October 2007, February 2008) were surveyed with two extra modules, one on cognitive skills, and one on risk preferences. 
For practical reasons, however, the module on risk preferences had to be restricted to natives only.

The second wave following one year after the first wave was primarily intended to update longitudinal information of the base module. The cohorts subject to the two extra modules on cognitive skills and risk preferences were also run through an update section regarding risk preferences and cognitive skills. These cohorts were also interviewed in an additional interim survey six months after the first wave. The difference between the two types of cohorts is depicted in Chart 5 .

\section{Chart 5: Cohort specific survey modules}

Cohorts 6/2007, 10/2007, and 2/2008
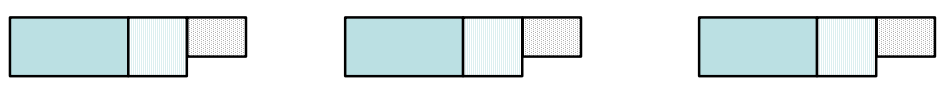

Cohorts 7-9/2007, 11-12/2007, 1/2008, and 3-5/2008

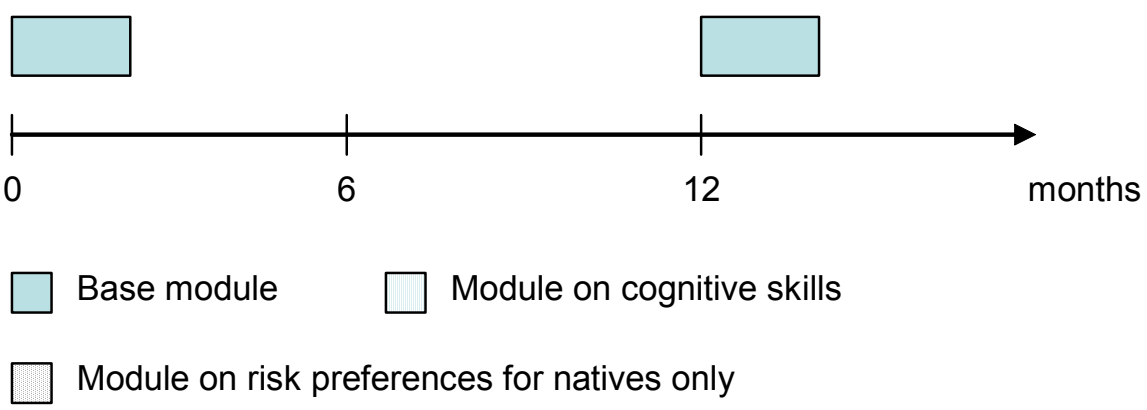

The survey institute was requested to conduct between 1,400 and 1,500 successful interviews per cohort in wave 1, based on random draws from the AST samples. Due to the restricted fieldwork phase of four weeks, the success rate of completed interviews compared to the number of phone contacts is relatively low (see Table 4). A higher success rate would have required fieldwork phases of up to six months, which was not 
acceptable in our case. The trade-off for close-to-event surveying consists in a potential selectivity bias linked to the ease of availability of respondents. In wave 1, no interview was possible for $29.9 \%$ of the attempted contacts and more than one-third of the potential interviewees refused to give one. Reasons for sample attrition are displayed in more detail in Table 5.

\section{Table 4: $\quad$ Sample Sizes, AST and Survey of the IZA Evaluation Dataset, Wave 1}

\begin{tabular}{|c|c|c|c|c|c|c|c|c|c|c|}
\hline Cohort & $\begin{array}{l}\text { Unscreened } \\
\text { AST }\end{array}$ & $\begin{array}{c}\text { Screened } \\
\text { AST }\end{array}$ & $\begin{array}{c}\text { AST } \\
\text { sample }\end{array}$ & $\begin{array}{l}\text { Contact } \\
\text { letters }\end{array}$ & $\begin{array}{l}\text { Phone } \\
\text { contact } \\
\text { s }\end{array}$ & $\begin{array}{c}\text { Inter- } \\
\text { view } \\
\text { not } \\
\text { possibl } \\
\text { e }\end{array}$ & $\begin{array}{l}\text { Refusal } \\
\mathbf{s}\end{array}$ & $\begin{array}{l}\text { Complet } \\
\text { ed inter- } \\
\text { views }\end{array}$ & $\begin{array}{c}\text { in \% of } \\
\text { phone } \\
\text { contacts }\end{array}$ & $\begin{array}{c}\text { Panel } \\
\text { agree- } \\
\text { ment } \\
\text { rate } \\
\text { (in \%) }\end{array}$ \\
\hline 06/2007 & 533,399 & 154,438 & 14,142 & 6,443 & 6,024 & 2,072 & 2,452 & 1,500 & 24.9 & 90.5 \\
\hline 07/2007 & 709,212 & 266,714 & 24,467 & 4,772 & 4,556 & 1,422 & 1,628 & 1,506 & 33.1 & 89.9 \\
\hline 08/2007 & 622,772 & 211,642 & 19,720 & 5,739 & 4,983 & 1,680 & 1,898 & 1,405 & 28.2 & 88.4 \\
\hline 09/2007 & 620,929 & 199,893 & 18,160 & 7,357 & 4,164 & 1,336 & 1,444 & 1,384 & 33.2 & 90.5 \\
\hline 10/2007 & 636,112 & 196,991 & 18,058 & 7,316 & 5,751 & 1,890 & 2,439 & 1,422 & 24.7 & 92.4 \\
\hline $11 / 2007$ & 617,322 & 187,731 & 16,756 & 7,252 & 4,599 & 1,336 & 1,725 & 1,538 & 33.4 & 90.9 \\
\hline $12 / 2007$ & 610,386 & 197,638 & 17,916 & 7,158 & 4,360 & 1,125 & 1,696 & 1,539 & 35.3 & 89.6 \\
\hline $01 / 2008$ & 802,741 & 361,523 & 32,531 & 7,197 & 3,910 & 929 & 1,580 & 1,401 & 35.8 & 89.4 \\
\hline 02/2008 & 596,876 & 195,172 & 17,122 & 7,113 & 4,607 & 1,213 & 1,893 & 1,501 & 32.6 & 92.5 \\
\hline 03/2008 & 592,083 & 172,363 & 15,220 & 7,078 & 3,845 & $1,0,66$ & 1,379 & 1,400 & 36.4 & 93.0 \\
\hline $04 / 2008$ & 608,731 & 184,535 & 16,313 & 7,022 & 3,937 & 1,087 & 1,449 & 1,401 & 35.6 & 91.9 \\
\hline 05/2008 & 565,522 & 147,059 & 12,905 & 6,952 & 4,225 & 1,251 & 1,575 & 1,399 & 33.1 & 91.1 \\
\hline$\sum$ (avg-\%) & $7,516,085$ & $2,475,699$ & 223,310 & 81,399 & 54,961 & 16,407 & 21,158 & 17,396 & 31.7 & 90.8 \\
\hline
\end{tabular}

Source: IAB documentation, own computations.

On average, more than $90 \%$ of the respondents agreed to be interviewed in follow-up waves. Since only those people were contacted again, the rate of successfully completed interviews is much higher in the interim wave and wave 2. Moreover, the fieldwork phase was extended to two months in both of these waves in order to increase the participation rate. For the follow-up interviews, timing of the interviews was not regarded as crucial as it had been for the initial wave. 
As a result, the participation rate in the follow-up waves increased to almost $70 \%$ on average. However, a problem occurred with respondents of the interim wave regarding their willingness to participate in wave 2 as well. As can be seen from Table 6, with a value of $58.4 \%$, the participation rate of these cohorts is significantly lower than the participation rate of the remaining cohorts, which averages $70.9 \%$. However, this does not seem to affect the socio-demographic structure of the related samples as might be concluded from Table 10. Table 7 gives a complete overview about conducted interviews in each wave by survey module.

\section{Table 5: Interview Contacts and Completed Interviews}

\begin{tabular}{|c|c|c|c|c|c|c|}
\hline \multirow[b]{2}{*}{$\sum$ Total number of contacted individuals } & \multicolumn{2}{|c|}{ Wave 1} & \multicolumn{2}{|c|}{ Interim Wave } & \multicolumn{2}{|c|}{ Wave 2} \\
\hline & 54,961 & $100.0 \%$ & 3,613 & $100.0 \%$ & 13,053 & $100.0 \%$ \\
\hline$-\Sigma$ No interview possibility & 16,407 & $29.9 \%$ & 415 & $11.5 \%$ & 1,520 & $11.6 \%$ \\
\hline - sampling criteria did not apply & 7,430 & $13.5 \%$ & - & - & - & - \\
\hline - inactive phone number ${ }^{1}$ & 6,529 & $11.9 \%$ & 344 & $9.5 \%$ & 1,253 & $9,6 \%$ \\
\hline - invalid address ${ }^{2}$ & 1,098 & $2.0 \%$ & 48 & $1.3 \%$ & 228 & $1.7 \%$ \\
\hline - insufficient language skills & 1,210 & $2.2 \%$ & 19 & $0.5 \%$ & 26 & $0.2 \%$ \\
\hline - not capable of performing interview ${ }^{3}$ & 140 & $0.3 \%$ & 4 & $0.1 \%$ & 13 & $0.1 \%$ \\
\hline$-\Sigma$ Refusal of interviews & 21,158 & $38.5 \%$ & 650 & $18.0 \%$ & 2,618 & $20.1 \%$ \\
\hline - household refused to give information & 1,785 & $3.2 \%$ & 93 & $2.6 \%$ & 369 & $2.8 \%$ \\
\hline - individual refused to give information & 2,925 & $5.3 \%$ & 110 & $3.0 \%$ & 449 & $3.4 \%$ \\
\hline - not at all interested in interviews & 7,090 & $12.9 \%$ & 161 & $4.5 \%$ & 728 & $5.6 \%$ \\
\hline - no time available for interview & 3,011 & $5.5 \%$ & 107 & $3.0 \%$ & 436 & $3.3 \%$ \\
\hline - duration of interview too long & 1,229 & $2.2 \%$ & 36 & $1.0 \%$ & 145 & $1.1 \%$ \\
\hline - interview was cancelled & 532 & $1.0 \%$ & 22 & $0.6 \%$ & 80 & $0.6 \%$ \\
\hline - data protection reasons & 728 & $1.3 \%$ & 14 & $0.4 \%$ & 47 & $0.4 \%$ \\
\hline - other reasons ${ }^{4}$ & 3,858 & $7.0 \%$ & 107 & $3.0 \%$ & 364 & $2.8 \%$ \\
\hline Completed interviews & 17,396 & $31.7 \%$ & 2,548 & $70.5 \%$ & 8,915 & $68.3 \%$ \\
\hline Not contacted by phone & & 438 & & & & \\
\hline \multicolumn{7}{|l|}{ Notes: } \\
\hline \multicolumn{7}{|c|}{1 phone number not activated/wrong phone number/fax or modem-number } \\
\hline \multicolumn{7}{|c|}{${ }^{2}$ respondent has moved to unknown destination/respondent unknown under given address } \\
\hline \multicolumn{7}{|c|}{${ }^{3}$ respondent deceased/respondent is handicapped/respondent has hearing problems } \\
\hline \multicolumn{7}{|c|}{$\begin{array}{l}{ }^{4} \text { unsuitable interview topic/too many surveys on that topic/telephone interview is not suitable/current sickness of interviewee/denied permission to gi } \\
\text { an interview by another household member }\end{array}$} \\
\hline
\end{tabular}


The base interviews in wave 1 took 43 minutes on average and 29 minutes in wave 2 (see Table 8). The two extra modules on risk preferences and cognitive skills applied to cohorts 1,5 , and 9 took an additional 15 minutes on average in wave 1 and somewhat less in subsequent waves. The survey data can be merged with employment history data from the IEB. In order to do so, respondents had to be asked for their consent in wave 1. However, for data protection reasons, we are only allowed to link information retrospectively up to the point in time of the interview. Table 9 shows the number of respondents who agreed upon merging survey data with administrative data. On average, almost $90 \%$ of the respondents approved our request.

\section{Table 6: $\quad$ Sample Sizes of the Survey of the IZA Evaluation Dataset, Wave 2}

\begin{tabular}{lrrrrr}
\hline \hline Cohort & $\begin{array}{c}\text { Respon- } \\
\text { dents } \\
\text { con- } \\
\text { tacted }\end{array}$ & $\begin{array}{c}\text { Inter- } \\
\text { view not } \\
\text { possible }\end{array}$ & Refusals & $\begin{array}{c}\text { Complet } \\
\text { ed inter- } \\
\text { views }\end{array}$ & $\begin{array}{c}\text { in \% of } \\
\text { phone } \\
\text { contacts }\end{array}$ \\
\hline $06 / 2007$ & 776 & 89 & 230 & 457 & 58.9 \\
$07 / 2007$ & 1,081 & 128 & 201 & 752 & 69.6 \\
$08 / 2007$ & 1,115 & 147 & 200 & 768 & 68.9 \\
$09 / 2007$ & 1,105 & 138 & 206 & 761 & 68.9 \\
$10 / 2007$ & 949 & 129 & 259 & 561 & 59.1 \\
$11 / 2007$ & 1,214 & 132 & 214 & 868 & 71.5 \\
$12 / 2007$ & 1,221 & 138 & 253 & 830 & 68.0 \\
$01 / 2008$ & 1,128 & 101 & 220 & 807 & 71.5 \\
$02 / 2008$ & 995 & 172 & 252 & 571 & 57.4 \\
$03 / 2008$ & 1,201 & 128 & 216 & 857 & 71.4 \\
$04 / 2008$ & 1,145 & 99 & 209 & 837 & 73.1 \\
$05 / 2008$ & 1,123 & 119 & 158 & 846 & 75.3 \\
\hline Total & $\mathbf{1 3 , 0 5 3}$ & $\mathbf{1 , 5 2 0}$ & $\mathbf{2 , 6 1 8}$ & $\mathbf{8 , 9 1 5}$ & $\mathbf{6 8 . 3}$ \\
\hline Cohorts with interim wave & 2,720 & 390 & 741 & 1,589 & 58.4 \\
Cohorts without interim wave & 10,333 & 1,130 & 1,877 & 7,326 & 70.9 \\
\hline
\end{tabular}

Source: infas (2010); own computations

Notes: cohorts with interim waves after six months marked in italics. 
Table 7: Number of cases by survey module

\begin{tabular}{|c|c|c|c|c|c|c|c|c|c|}
\hline \multirow[b]{2}{*}{ Cohort } & \multicolumn{3}{|c|}{ Initial wave } & \multicolumn{3}{|c|}{ Interim wave } & \multicolumn{3}{|c|}{ Wave 2} \\
\hline & $\begin{array}{c}\text { Base } \\
\text { module }\end{array}$ & $\begin{array}{c}\text { Module } \\
\text { on } \\
\text { cognitive } \\
\text { skills }\end{array}$ & $\begin{array}{c}\text { Module } \\
\text { on risk } \\
\text { preferen- } \\
\text { ces }\end{array}$ & $\begin{array}{c}\text { Base } \\
\text { module }\end{array}$ & $\begin{array}{c}\text { Module } \\
\text { on } \\
\text { cognitive } \\
\text { skills }\end{array}$ & $\begin{array}{c}\text { Module } \\
\text { on risk } \\
\text { preferen- } \\
\text { ces }\end{array}$ & $\begin{array}{l}\text { Base } \\
\text { module }\end{array}$ & $\begin{array}{c}\text { Module } \\
\text { on } \\
\text { cognitive } \\
\text { skills }\end{array}$ & $\begin{array}{c}\text { Module } \\
\text { on risk } \\
\text { preferen- } \\
\text { ces }\end{array}$ \\
\hline $06 / 2007$ & 1,500 & 1,500 & 1,297 & 853 & 853 & 742 & 457 & 457 & 391 \\
\hline $07 / 2007$ & 1,506 & & & & & & 752 & & \\
\hline $08 / 2007$ & 1,405 & & & & & & 768 & & \\
\hline 09/2007 & 1,384 & & & & & & 761 & & \\
\hline $10 / 2007$ & 1,422 & 1,422 & 1,274 & 857 & 857 & 771 & 561 & 561 & 507 \\
\hline $11 / 2007$ & 1,538 & & & & & & 868 & & \\
\hline $12 / 2007$ & 1,539 & & & & & & 830 & & \\
\hline $01 / 2008$ & 1,401 & & & & & & 807 & & \\
\hline $02 / 2008$ & 1,501 & 1,501 & 1,305 & 838 & 838 & 747 & 571 & 571 & 502 \\
\hline $03 / 2008$ & 1,400 & & & & & & 857 & & \\
\hline $04 / 2008$ & 1,401 & & & & & & 837 & & \\
\hline $05 / 2008$ & 1,399 & & & & & & 846 & & \\
\hline Total & 17,396 & 4,423 & 3,876 & 2,548 & 2,548 & 2,260 & 8,915 & 1,589 & 1,400 \\
\hline
\end{tabular}

Source: infas (2009); infas (2010). 
Table 8: Average duration of interviews in minutes by survey module

\begin{tabular}{|c|c|c|c|c|c|c|c|c|c|}
\hline \multirow[b]{2}{*}{ Cohort } & \multicolumn{3}{|c|}{ Initial wave } & \multicolumn{3}{|c|}{ Interim wave } & \multicolumn{3}{|c|}{ Wave 2} \\
\hline & $\begin{array}{c}\text { Base } \\
\text { module }\end{array}$ & $\begin{array}{c}\text { Module } \\
\text { on } \\
\text { cognitive } \\
\text { skills }\end{array}$ & $\begin{array}{c}\text { Module } \\
\text { on risk } \\
\text { preferen- } \\
\text { ces }\end{array}$ & $\begin{array}{c}\text { Base } \\
\text { module }\end{array}$ & $\begin{array}{c}\text { Module } \\
\text { on } \\
\text { cognitive } \\
\text { skills }\end{array}$ & $\begin{array}{l}\text { Module } \\
\text { on risk } \\
\text { preferen- } \\
\text { ces }\end{array}$ & $\begin{array}{c}\text { Base } \\
\text { module }\end{array}$ & $\begin{array}{c}\text { Module } \\
\text { on } \\
\text { cognitive } \\
\text { skills }\end{array}$ & $\begin{array}{c}\text { Module } \\
\text { on risk } \\
\text { preferen- } \\
\text { ces }\end{array}$ \\
\hline $06 / 2007$ & 46 & 7 & 9 & 14 & 6 & 6 & 31 & 4 & 8 \\
\hline $07 / 2007$ & 42 & & & & & & 27 & & \\
\hline $08 / 2007$ & 44 & & & & & & 31 & & \\
\hline 09/2007 & 42 & & & & & & 27 & & \\
\hline $10 / 2007$ & 43 & 7 & 8 & 15 & 6 & 6 & 30 & 4 & 8 \\
\hline $11 / 2007$ & 43 & & & & & & 27 & & \\
\hline $12 / 2007$ & 42 & & & & & & 32 & & \\
\hline $01 / 2008$ & 42 & & & & & & 28 & & \\
\hline $02 / 2008$ & 44 & 7 & 7 & 16 & 6 & 6 & 31 & 4 & 8 \\
\hline $03 / 2008$ & 43 & & & & & & 25 & & \\
\hline $04 / 2008$ & 42 & & & & & & 31 & & \\
\hline $05 / 2008$ & 43 & & & & & & 26 & & \\
\hline Total & 43 & 7 & 8 & 15 & 6 & 6 & 29 & 4 & 8 \\
\hline
\end{tabular}

Source: infas (2009); infas (2010); own computations.

Table 9: Willingness to Merge Administrative Data (\% in parentheses)

\begin{tabular}{cc|cc|}
\hline \hline Cohort & $\begin{array}{c}\text { (1) Completed } \\
\text { interviews }\end{array}$ & \multicolumn{2}{|c|}{$\begin{array}{c}\text { (2) Willingness to merge } \\
\text { administrative data and survey }\end{array}$} \\
\hline $06 / 2007$ & 1,500 & 1,334 & $(88.9)$ \\
$07 / 2007$ & 1,506 & 1,339 & $(88.9)$ \\
$08 / 2007$ & 1,405 & 1,232 & $(87.6)$ \\
$09 / 2007$ & 1,384 & 1,207 & $(87.2)$ \\
$10 / 2007$ & 1,422 & 1,272 & $(89.5)$ \\
$11 / 2007$ & 1,538 & 1,329 & $(86.4)$ \\
$12 / 2007$ & 1,539 & 1,314 & $85.4)$ \\
$01 / 2008$ & 1,401 & 1,204 & $(85.9)$ \\
$02 / 2008$ & 1,501 & 1,358 & $(90.5)$ \\
$03 / 2008$ & 1,400 & 1,239 & $(88.5)$ \\
$04 / 2008$ & 1,401 & 1,225 & $(87.4)$ \\
$05 / 2008$ & 1,399 & 1,221 & $(87.3)$ \\
\hline$\Sigma$ & 17,396 & $\mathbf{1 5 , 2 7 4}$ & $\mathbf{( 8 7 . 8 )}$ \\
\hline \hline
\end{tabular}

Source: infas (2009); own computations. 
Some basic descriptives for the unscreened and screened AST, the AST-sample and the survey data of the IZA Evaluation Dataset are displayed in Table 10. Compared to the AST sample, some minor deviations occur in the survey sample of wave $1^{5}$. These differences may have to do with the screening procedure described above, but may also point to a selectivity issue. Women seem to have been more willing to participate in the initial wave, whereas the opposite seems to be the case for non-natives and younger individuals. The differences persist in later waves although attrition may vary by category. For example, the probability of natives to participate in subsequent waves is more than 10 percentage points higher than for non-natives. Nevertheless, the effect on the marginal distribution is rather small. The changes that occur with regard to age are in addition reflecting the aging of the sample, which has no substantial meaning at all. However, the likelihood of staying in the sample seems to increase with age.

Table 10: Distribution (in \%) of Sex, Citizenship and Age in AST and IZA Samples

\begin{tabular}{lcccccc}
\hline \hline $\begin{array}{l}\text { Databasel } \\
\text { Wave }\end{array}$ & $\begin{array}{c}\text { Unscreened } \\
\text { AST }\end{array}$ & $\begin{array}{c}\text { Screened } \\
\text { AST }\end{array}$ & $\begin{array}{c}\text { AST } \\
\text { sample }\end{array}$ & Wave 1 & $\begin{array}{c}\text { Interim } \\
\text { wave }^{*}\end{array}$ & Wave $2^{*}$ \\
\hline Male & 54.8 & 55.9 & 56.0 & 52.6 & $52.4(57.5)$ & $52.1(50.7)$ \\
Female & 45.2 & 44.1 & 44.0 & 47.4 & $47.6(57.7)$ & $47.9(51.8)$ \\
\hline Natives & 86.3 & 90.3 & 91.0 & 94.2 & $94.4(58.3)$ & $95.5(51.9)$ \\
Non-natives & 13.7 & 9.7 & 9.0 & 5.8 & $5.6(47.8)$ & $4.5(40.1)$ \\
\hline $16-24$ & 21.9 & 28.8 & 28.6 & 25.2 & $22.9(51.9)$ & $17.6(41.7)$ \\
$25-34$ & 24.1 & 26.6 & 26.5 & 27.1 & $26.7(53.9)$ & $27.0(49.0)$ \\
$35-44$ & 24.1 & 24.2 & 24.3 & 24.7 & $24.7(61.2)$ & $26.4(56.3)$ \\
$45-54$ & 21.7 & 20.4 & 20.6 & 21.8 & $23.5(65.5)$ & $25.9(59.3)$ \\
$55+$ & 8.2 & 0.1 & 0.1 & 1.2 & $2.1(67.9)$ & $3.1(54.0)$ \\
\hline \hline
\end{tabular}

Notes: *In parentheses: probability of realized interview, given that individual participated in wave 1 ; for age groups, the related percentages refer to the age category in wave 1.

Source: IAB documentation, own computations.

5 The emergence of individuals older than 54 in the screened samples is due to the fact that those individuals have not yet passed the age of 54 at the time of being selected for the survey. 


\section{Outlook}

The IZA Evaluation Dataset offers unique research opportunities for the assessment of the impact of labor market policy on various outcomes. It is especially the detailed and innovative survey data, together with a solid statistical basis, that provides promising new research perspectives which have not been met with previous datasets. Moreover, the IZA Evaluation Dataset is an important step towards evidence-based policy-making. It will help to improve our understanding of relevant processes in the labor market and also our understanding of the conditions under which policy instruments are likely to work well or poorly. This is forcefully documented by the first papers based on this dataset which have already emerged.

Caliendo, Cobb-Clark and Uhlendorff (2010), for example, show that job search strategies crucially depend on subjective beliefs about the pay-off of individual search efforts. Those who believe in the effectiveness of their search effort set higher reservation wages and search more intensively than others. As a consequence, it might be useful for public placement agencies to assist especially those who tend to underestimate the link between individual search effort and successful job search. Caliendo, Tatsiramos and Uhlendorff (2009) investigate the role of the duration of unemployment benefits for the quality of job matches. Their findings indicate that the reduction of maximum duration of unemployment compensation from 18 to 12 months

during the labor market reform in Germany has significantly reduced the quality of job matches. Unemployment duration is also the focus of a paper by Dohmen et al. (2010), who address the role of cognitive and non-cognitive skills in this process. 
An interesting ex-ante effect of active labor market programs is examined by van den Berg, Bergemann and Caliendo (2009), who show that unemployed job-seekers try to prevent being sent on such programs by lowering their reservation wage and intensifying their job search activities when assigned to program participation. This could mean that part of the positive effect of program participation would in fact have to be attributed to this pre-program effect. Bergemann, Caliendo, van den Berg and Zimmermann (2010) show that these anticipation effects operate differently for natives and migrants. Constant et al. (2009) focus on re-employment prospects of migrants. Aside from the known fact that migrants face more difficulties in finding a new job than natives, this study shows that this is especially true for migrants who are only weakly integrated. Constant et al. (2010) examine whether there are differences in the economic preferences and attitudes between natives and second-generation migrants. They find differences especially in terms of risk attitudes and positive reciprocity and show that these are relevant for (re-)employment probabilities. Last but not least, Schneider (2008) provides evidence that reservation wages have fallen remarkably since the labor market reforms in Germany between 2003 and 2005 . This may serve as a key explanation for the exceptional decline of unemployment since 2005.

There are many more papers based on the IZA Evaluation Dataset being currently drawn up, but the research potential of this rich dataset has yet to be exhausted. With the completion of the third survey wave in May 2011, the prospects for innovative and stimulating research will be even more elevated. 


\section{References}

Anger, S. and Heineck, G. (2010), "Do Smart Parents Raise Smart Children? The Intergenerational Transmission of Cognitive Abilities", Journal of Population Economics, Vol 23 No. 3, pp. 1105-1132.

Aydemir, A. (2011), "Immigrant Selection and Short-term Labour Market Outcomes by Visa Category", forthcoming in Journal of Population Economics, published online: DOI No. 10.1007/s00148-0090285-0.

Bergemann, A., Caliendo, M., Van den Berg, G.J. and Zimmermann, K.F. (2010), "The Threat Effect of Participation in Active Labor Market Programs on Job Search Behavior of Migrants in Germany", IZA Discussion Paper, Institute for the Study of Labor, Bonn.

Black, D., Smith, J., Berger, M. and Noel, B. (2003), "Is the Threat of Reemployment Services More Effective than the Services Themselves? Evidence from Random Assignment in the UI System", American Economic Review, Vol 93 No. 4, pp. 1313-1327.

Bonin, H., Dohmen, T., Falk, A., Huffman, D. and Sunde, U. (2007), "Cross-sectional Earnings Risk and Occupational Sorting: The Role of Risk Attitudes”, Labour Economics, Vol. 14 No.6, pp. 926-937.

Borghans, L., Duckworth, A.L., Heckman, J.J. and Weel, B. ter (2008), "The Economics and Psychology of Personality Traits”, Journal of Human Resources, Vol. 43 No. 4, pp. 972-1059.

Bundesagentur für Arbeit (2009), "Methodenbericht der BA-Statistik: Umfassende Arbeitsmarkstatistik", Nürnberg.

Caliendo, M., Cobb-Clark, D. and Uhlendorff, A. (2010), "Locus of Control and Job Search Strategies", IZA Discussion Paper No. 4750, Institute for the Study of Labor, Bonn.

Caliendo, M., Hujer, R., Thomsen, S. (2008), "The Employment Effects of Job Creation Schemes in Germany - A Microeconometric Evaluation”, in Millimet, D., Smith, J. and Vytlacil, E. (Eds.), Advances in Econometrics, Volume 21: Estimating and Evaluating Treatment Effects in Econometrics, Elsevier: Oxford, Amsterdam, San Diego, pp. 383-430.

Caliendo, M., Tatsiramos, T. and Uhlendorff, A. (2009), "Benefit Duration, Unemployment Duration and Job Match Quality: A Regression-Discontinuity Approach", IZA Discussion Paper No. 4670, Institute for the Study of Labor, Bonn.

Constant, A, Gataullina, L. and Zimmermann, K.F. (2009), "Ethnosizing Immigrants", Journal of Economic Behavior and Organization, Vol. 69 No. 3, pp. 274-287.

Constant, A., Kahanec, M., Rinne, U. and Zimmermann, K.F. (2009), "Ethnicity, Job Search and Labor Market Reintegration of the Unemployed", IZA Discussion Paper No. 4660, Institute for the Study of Labor, Bonn.

Constant, A., Krause, A., Rinne, U. and Zimmermann, K.F. (2010), "Economic Preferences and Attitudes of the Unemployed: Are Natives and Second Generation Migrants Alike?", IZA Discussion Paper, Institute for the Study of Labor, Bonn.

Constant, A., Roberts, R. and Zimmermann, K.F. (2009), "Ethnic Identity and Immigrant Homeownership", Urban Studies, Vol. 46 No. 9, pp. 1879-1898. 
Constant, A. and Zimmermann, K.F. (2008), "Measuring Ethnic Identity and Its Impact on Economic Behavior", Journal of the European Economic Association, Vol. 6 No. 2-3, pp. 424-433.

Crépon, B., Ferracci, M. and Fougère, D. (2007), "Training the Unemployed in France: How Does It Unemployment Duration and Recurrence", IZA Discussion Paper No. 3215, Institute for the Study of Labor, Bonn.

Dohmen, T., Falk, A., Huffman, D., Jaeger, S. and Sunde, U. (2010), "The Effect of Cognitive and NonCognitive Skills on Unemployment Duration", mimeo, Bonn.

Dundler, A. (2006), "Description of the Person-Related Variables from the Datasets IEBS, IABS and LIAB", mimeo, Nürnberg.

Fitzenberger, B. and Völter, R. (2007), "Long-Run Effects of Training Programs for the Unemployed in East Germany”, Labour Economics, Vol. 14 No. 4, pp. 730-755.

Heinrich, C.J., Mueser, P.R. and Troske, K.R. (2005), "Welfare to Temporary Work: Implications for Labor Market Outcomes", Review of Economics and Statistics, Vol. 87 No. 1, pp. 154-173.

infas (Institut für angewandte Sozialwissenschaft) (2009), "Feldreport "Arbeitsmarktchancen in Deutschland" - Befragung Arbeitsloser aus einer administrativen Stichprobe. Wellen 1 und Zwischenmessung", mimeo, Bonn.

infas (Institut für angewandte Sozialwissenschaft) (2010), "Feldreport "Arbeitsmarktchancen in Deutschland" - Befragung Arbeitsloser aus einer administrativen Stichprobe. Welle 2", mimeo, Bonn.

Jacobebbinghaus, P. and Seth, S. (2007), "The German Integrated Employment Biographies Sample IEBS”, Schmollers Jahrbuch, Vol. 127 No. 2, pp. 335-342.

Jaenichen, U., Kruppe, T., Stephan, G., Ullrich, B. and Wießner, F. (2005), "You Can Split It If You Really Want. Korrekturvorschläge für ausgewählte Inkonsistenzen in IEB und MTG”, mimeo, Nürnberg.

Kruppe, T., Müller, E., Wichert, L. and Wilke, R.A. (2008), "On the Definition of Unemployment and Its Implementation in Register Data. The Case of Germany", Schmollers Jahrbuch, Vol. 128 No. 3, pp. 461-488.

Lechner, M., Miquel, R. and Wunsch, C. (2007), "The Curse and Blessing of Training the Unemployed in a Changing Economy: The Case of East Germany after Unification”, German Economic Review, Vol. 8 No. 4 , pp. 468-509.

Schneider, H. (2008), "Die Veränderung der Lohnersatzleistungen und die Reform der Vermittlungsprozesse im SGB III", Vierteljahreshefte zur Wirtschaftsforschung, Vol. 77 No. 1, pp. 20-37.

Schneider, H. and Uhlendorff, A. (2006), "Die Wirkung der Hartz-Reform im Bereich der beruflichen Weiterbildung”, Journal for Labour Market Research, Vol. 39 No. 3-4, pp. 477-490.

Sianesi, B. (2008), "Differential Effects of Active Labour Market Programs for the Unemployed", Labour Economics, Vol. 15 No. 3, pp. 370-399.

Van den Berg, G.J., Bergemann, A. and Caliendo, M. (2009), "The Effect of Active Labor Market Programs on Not-Yet Treated Unemployed Individuals", Journal of the European Economic Association, Vol. 7 No. 2-3, pp. 606-616. 
Zimmermann, R., Kaimer, S. and Oberschachtsiek, D. (2007), "Dokumentation des "Scientific Use Files der Intergrierten Erwerbsbiographien” (IEBS-SUF V1) Version 1.0”, FDZ Datenreport No. 1, Institute for Employment Research, Nürnberg. 